\title{
Tissue Decellularization
}

National Cancer Institute

\section{Source}

National Cancer Institute. Tissue Decellularization. NCI Thesaurus. Code C112947.

The physical, chemical and/or enzymatic processing of tissue samples to remove cells

and leave behind the extracellular matrix or natural scaffold made up of collagen and other fibers and proteins. 